\title{
A Phonological Analysis of Segmental Phonemes in
} Standard English

D. Shaymaa Yaseen Thabit,M.A

Assist.Prof. Muslih Shwaysh Ahmed.Ph.D

College of Education for Humanities

\section{Abstract:}

The phonological analysis of phonemes as segments including consonants and their allophones, consonant clusters, and vowels with their allophones that may work in complementary distribution or in free variation with each other are tackled in this paper beside sounds in context to show how sounds produced in rapid connected speech reveal affection to each other producing utterances colored by assimilation, elision, and intrusion. The paper aims to show the different sub-types of these phonological processes such as coalescent assimilation, syncopic elision, and epenthetic intrusion. The paper is a reprint of an edited chapter of an M.A. thesis entitled " A Phonological Analysis of Segmental Phonemes in Standard English and Hit Iraqi Arabic " to be presented in confirming with the requirements for an M.A. degree.

\section{Introduction}

This paper deals with sounds as segments that constitute the smallest parts of an uttered word and may work in complimentary distribution or in free variation for each sound segment has varying allophones. It also tackles sounds in context, namely; assimilation which is divided to three sub groupings according to direction of influence: progressive, regressive, and coalescent; elision that has three sub groupings according to the position of the elided segment: aphaeresis , syncope , and apocope; intrusion is also subdivided to three groups according to the position of the inserted segment: prothesis, epenthesis, and anaptyxis.

Consonants can be divided into a number of sub groupings on the basis of their manner and place of articulation. Davenport and Hannahs (2005: 19) state that the consonantal articulation types, starting with those having the narrowest strictures, the stops and affricates ,moving through more open strictures to the fricatives and then to nasals and liquids ending with the class with the widest stricture settings, the glides. In each class of consonants, there is a description of its production at different places of articulation and a discussion of any significant variation exhibited. 


\section{Consonants}

They include five types of consonant phonemes including stops, fricatives, affricates, nasals, and approximants.

\subsection{Obsruents}

These include stops, fricatives, and affricates.

\subsubsection{Stops}

Plosive consonants have articulators which may form a stricture of complete closure. They are six in number : / b/, /d/, /g/, which are voiced bilabial , alveolar, and velar stops ; while $/ \mathrm{p} /, \mathrm{t} / / / \mathrm{k} /$ are voiceless bilabial , alveolar, and velar stops respectively. They occur initially, medially, and finally in a syllable. Clark and Yallop ( $1995: 24)$ state that when a voiced stop follows a liquid, a nasal, or a vowel it causes that

sound or segment to lengthen, compare the duration of the penultimate segments in

\section{Gulp vs. bulb}

In each case, the segment preceding the voiced stop is notably longer than that preceding the voiceless stop . There is also the glottal stop /?/ which is only a representation of coarticulation of $/ \mathrm{p} /, / \mathrm{t} /, / \mathrm{k} /$ in certain contexts, as in the following examples

2. Butter $\rightarrow \quad[\mathrm{b} \Lambda \mathrm{Pa}]$

3. Pit $\rightarrow \quad[\mathrm{h}$ Pt $] \quad$ (Carr $2009: 7)$

The voiceless stops have aspirated allophones that are produced with a puff of air when they happen to occur word- initially, and is symbolized by [h]. The voiced stops /b/, /d/ have devoiced allophones, wholly or partially, when they occur in initial position in a word, in final position, or post-vocalically, as in the following examples

4. Beetle $\rightarrow$ [ bi:tł ]

5. Dog $\rightarrow[\mathrm{d}$ dog ] (Davenport and Hannahs 20005

Preceding the palatal $/ \mathrm{j} /$, plosives are palatalized and symbolized by $[\mathrm{j}]$ following the plosive, as in the following examples

6 . She is a beauty $\rightarrow[$ [i: $z$ ə bjju:tI $]$

7. He is the Duke $\rightarrow[$ hi:z ðə djjuk ]

8. Pure is water $\rightarrow[\mathrm{p}$ jjuə Iz wotə $]$

(Collins \&Mees 2008:95)

The alveolar plosives /t/, /d/ are advanced to dental position when adjacent to dental fricatives, and is symbolized by [ ${ }_{n}$ ] below the sound. Whereas $/ \mathrm{k} /, / \mathrm{g} /$ the velar closure is advanced before front vowels and $/ \mathrm{y} /$ symbolized by $[+]$ after the sound The velar closure is retracted before back vowels, symbolized by [-], as in the following examples

9. Eighth..[ eit $\Theta$ ]

10. Hid them there..[ hid ðəm ðеə ]

11. Give me the key. .. [ gImmI ðə k+i: ] 


\subsubsection{Fricatives}

There is no closure between the active and passive articulators, but there is a narrowing between them causing audible friction when air coming from the lungs passes between the two articulators. Fricatives in $\mathrm{SE}$ are nine in number including the glottal $/ \mathrm{h} /$. The other eight fricatives include the labio-dental /v/, the dental /ð/, the alveolar / z /, and the palatoalveolar $/ 3 /$, which are all voiced fricatives; alongside the voiceless ones which include the labio-dental $/ \mathrm{f} /$,the dental $/ \Theta /$ the alveolar $/ \mathrm{s} /$, and the palato-a1veolar/ $\int /$ (Rajimwale 2007: 125). The distribution of the fricatives $/ \mathrm{f} /, / \mathrm{v} /, / \Theta /, / \mathrm{d} /, / \mathrm{s} /, / \mathrm{z} /, / \mathrm{f} /$ shows that they can occur in all positions in SE, i.e. initially, medially, and finally in a syllable. While /3/, / $\mathrm{h} /$ are restricted to medial and final positions, but never initially for $/ 3 /$. The glottal $/ \mathrm{h} /$ occurs initially or medially at the beginning of stressed syllables, but never finally( Davenport and Hannahs $2005: 24)$.

The voiced fricatives have devoiced allophones when they occur word- initially and word- finally, as in the following examples:

13. Its vague $\rightarrow$ [its veig]

14. Do it for God's sake $\rightarrow$ [dv it fo: godz serk]

The $[\mathrm{v}]$ is partially devoiced as compared with " saving ".

Ladefoged (2006: 72) states that obstruents - stops and fricatives, classified as voiced /b/, /d/, /g/, /v/, /z/,/3/, are devoiced when they occur at the end of an utterance or before a voiceless sound. Fricatives have also palatalized allophones, and some are labialized when preceding /w/, as in the following example:

15. I switched the fuse $\rightarrow$ [ a s $\mathrm{s}^{\mathrm{w}} \mathrm{wit} \int \mathrm{ft}$ ðə fjoz ]

(Collins and Mees 2008:95)

\subsubsection{Affricates}

Affricates are another type of obstruents. They begin as plosives /t/, /d/, and end as fricatives / $/$ /, /3/, consequently. Roach (2000: 48) and (Zsiga 2006: 21) state that an affricate begins with an articulation practically the same as that for $/ \mathrm{t} /$, but instead of a rapid release with plosion and aspiration, the tongue moves to the position of the fricative $/ \mathrm{J} /$ producing $/ \mathrm{t} \mathrm{f} /$ as a voiceless affricate. Ladefoged (2006:66) states that it is simply a sequence of a stop followed by a homorganic fricative. The other affricate in SE is the voiced palato-alveolar/dz/. This voiced affricate has a devoiced allophone when syllable- initial, except when immediately preceded by a voiced sound.

\subsection{Nasals}


Since the airflow goes through the nasal cavity in the production of $/ \mathrm{m} /, / \mathrm{n} /, / \mathrm{n} /$, in SE , they are called nasals. Clark and Yallop (1995:48) state that nasal consonants have a stoppage at some point in the oral cavity; at the same time, the velum is lowered to allow airflow through the nasal cavity. The sounds are therefore perceived as stable and continuous rather than as stops in the true sense. They can be nasals $/ \mathrm{m} /$ and $/ \mathrm{n} /$ occur wordinitially, medially, and finally as in "mill, humor, ram" ; "nil, tuna, ran". The velar $/ \mathrm{y} /$ can not occur word-initially in SE, as in

" singer, rang " (Davenport and Hannahs 2005: 30). Nasals are syllabic at the end of a word when immediately after an obstruent, as in:

16. Chasm $\rightarrow$ [ kæzm ] $\quad$ (Ladefoged 2006: 74)

When nasals $/ \mathrm{m} /$ and $/ \mathrm{n} /$ follow a voiceless fricative $/ \mathrm{s} /$ in initial clusters , they have devoiced allophones symbolized by under the sound, as in the following example:

17. It's snowing $\rightarrow$ [ Its snovin ]

When occurring before labio-dental $/ \mathrm{f} /$ and $/ \mathrm{v} /$, both $/ \mathrm{m} /$ and $/ \mathrm{n} /$ have the labio-dental allophone $[\mathrm{m}]$ as in:

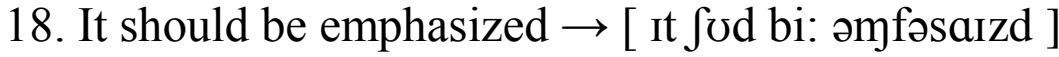

(Collins and Mees 2008: 94-96)

\subsection{Approximants}

These consonants can also be called semi-vowels. They are termed so because they lack full oral closures as in stops and fricatives, the lateral approximant is termed so because it is formed with the sides of the tongue lowered, so that airstream passes laterally around a central closure, usually at the alveolum (Hudson 2000: 23). They also include /w/, / j /, / r /, in SE. They are phonetically like vowels but phonologically like consonants. From the phonetic point of view, the articulation of $[\mathrm{j}]$ and [w]is practically the same as [i:] and [ $\mathrm{\sigma}]$ vowels consequently. The [r]is symbolized by [ə] in phonetic transcription at the end of a word or medially if not followed by a vowel (Roach 2000: 46). Phonologically speaking, they are treated as consonants because they can not be the nucleus of a syllable. While McMahon (2002 : 29) sees that approximants are four in number : /j/, as in: 'yes', /w/, as in ' wet', / $\mathrm{r} /$, as in 'red', and /1/ as in 'led'. All these approximants are voiced. They are at least partially devoiced when they occur after voiceless stops $/ \mathrm{p} /, / \mathrm{t} /, / \mathrm{k} /$, as in:

19. Play $\rightarrow$ [pleI]

(Ladefoged 2006: 72)

The $/ 1 /$ is velarised [ 1 ] when it occurs word-finally and before another consonant, as in:

20. Pill $\rightarrow[\stackrel{\mathrm{h}}{\text { pil }}]$

In SE, 'clear 1' occurs before vowels in the same syllable and before [ $\mathrm{j}]$ as in: 


\section{Million $\rightarrow$ [miljən]}

(Catford 1977: 199)

\section{Consonant Clusters}

SE consonant clusters can be defined as the sequence of adjacent consonants occurring initially or finally in a syllable such as initial [br-] of "bright", or final [-st] of "beast". Not all combinations of consonants occur in a language. Cohen (2003:180) states that our knowledge of the sound patterns of our native language comes by internalizing information about the allowed and disallowed sound patterns of that language. Initially in syllables in English, for example, clusters are not possible with $/ \Theta /, / \mathrm{t} /, / \mathrm{d} /$, /z/ .Up to three consonants can occur initially, as in "street" [str-].

\subsection{Initial CCs}

Initially in English syllables, clusters are not possible with $[\Theta, t, d, z]$ and up to three consonants can occur, such as [spr-, skw-, spl- ] as in the following examples:

22. Spray $\rightarrow$ [ spreI ]

\section{Splendid $\rightarrow$ [ splendəd ]}

(Crystal s.v. 77)

Two-segment initial clusters such as [ pl, tr, bl, dr, vj, fr ] are found in English as in the following examples:

24. Play $\rightarrow$ [ plein ]

25. Tree $\rightarrow$ [ tri: ]

(Rajimwale 2007: 143)

\subsection{Medial CCs}

Medial CCs can occur in the middle of words between two vowels. Such clusters include two, three, and four consonant segments, such as [- lt -, -mpt- , - kskl - ] as in the following example:

28. Exclude $\rightarrow$ [ eksklu:d ] (A1-Hamash 1984: 63)

\subsection{Final CCs}

These can occur up to four consonant segments finallyin a word, such as [-mpst, - lfӨs] as in the following example:

\section{(Crystal s.v. 78) 29. Glimpsed $\rightarrow$ [ glimpst ]}

Two and three consonant segments make clusters such as [ -sp, - -lb , kt, - ld, -sk, -pt] ; [- dst, - skt,- mpt, - nst, - ldz] are available in English.

\section{Vocalic Nuclei}

The vocalic nuclei of SE includes vowels, diphthongs, and triphthongs, which is mostly formed by the addition of the central vowel /a / to closing diphthongs. Vowels and diphthongs in SE are twenty in number. The description of the vocalic nuclei depends on three major articulatory criteria:

A) Tongue height (the relative height of the tongue in the mouth whether high, mid, or low).

B) Tongue advancement (the relative position of the tongue in the mouth, whether front, central, or back). 
C) Lip-rounding (the relative shape of the lips, whether spread, closerounded, open-rounded, or neutral) (Roach 2000:20).

Vowels and diphthongs have a distinctive syllabic function in English, twelve pure vowels and eight diphthongs (Rajimwale 2007: 109). Notations of pure vowels and diphthongs include closing and centering diphthongs: /

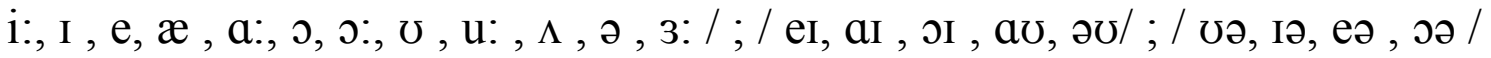
respectively. Phonologically, vowels function as the nucleuses of the syllables, i.e. the / I/ in " bıg" and the /æ / in "hat", are syllabic for they compromise the essential part of the syllable (Davenport and Hannahs 2005:63).

\subsection{Pure Vowels}

Vowels in SE are twelve as have been given by Gimson (1989: 101) and Jones (2009: 91) starting with the following:

: It is a short, front, half-close, unrounded vowel, as in: 1. / I / "sit", "ladies", "cities", "private".

2. / i: / : It is a long, high, close, front, unrounded vowel. The vowel is often diphthongised, especially in final position, a slight glide from a position near to / I / is common among RP speakers, being more usual than a pure vowel ( Gimson 1989:102), as in : " seat ", " meet ", " heat " 3. / e / : It is a short, front, between half-close and half-open position, lips are loosely spread, as in : " set ", "dead" , "many".

4 . / $æ /:$ It is a short, front, below half-open position with neutral lips , as in : " sat ", " pack ", " batch ".

$5 . / \Lambda /:$ It is a short, central, above the fully open position, lips neutrally open, as in: "cut", "son", "flood", "oven", (Jones 2009: 109).

6. / a: / : It is a long, back, open, neutrally open lips, as in: card " , " carve ", " hard ". " " retard ",

7. / $/$ / : It is a short, open, back, open-rounded lips, it does not occur in a final open syllable, as in : " gone "," because ", "dog". Many words containing / o / plus / $\mathrm{f}, \Theta, \mathrm{s} /$ have alternative pronunciation with /っ:/, as in : " cross ", " off ", " cloth " (ibid: 115).

8. / $: /$ : It is along, back, between half-open and half-close position, open-rounded lips, as in : " cord ", " born ", " oar ".

9. / $/$ : It is a short, back, half-close position, closely- rounded lips,

as in : " put ", " wood ", " look".

$\mathrm{u}: /$ : It is a long, back, close, lips closely rounded, as in: 10. /

food ", " spoon ", " June ".

11. / 3: / : It is a long, central, between half-open and half close position, lips neutrally spread, as in : " girle ", " purr"

" bird ", " earth ".

12. / a / : It is a short, central, neutral lip position, it has the high frequency of occurring in unaccented syllables, as in: 


\section{" possible ", "oblige ", "particular", "mother" (Roach 2000: 17).}

The English vowel / æ / has a nasalised allophone in syllables that are closed by a nasal consonant, as in : [ mæn] " man ", [bæn] " ban ". Vowels that occur before voiceless stops or fricatives are shorter than before voiced stops or fricatives (Ladefoged $2006: 65$ ).

\subsection{Diphthongs}

A diphthong can be defined as a vowel of continually changing quality, it can be described and identified in terms of its beginning and ending points with the assumption that the articulators take the shortest path between these points (Abercrombie 1971:60 ; Jones 2009: 100). Thus the diphthong in " noise " starts in a half-open position, back, rounded lips, and the tongue and lips move immediately to half-close, front, unrounded lips position. Diphthongs in SE are eight in number, three centering diphthongs / гə, və, eə / and five closing exclusion of /oə/ which is replaced by/o:/ in RP diphthongs with the ( Carr 2009:32 ;Roach 2000 :21). The distributions or major restrictions concerning short monophthongs vs. long ones and diphthongs are that short vowels may not occur finally in stressed monosyllabic words, while long vowels and diphthongs do. Short vowels can only occur in stressed monosyllables when these are consonant final, [bit] and [bog]. That is, short vowels are restricted to closed syllables in stressed monosyllabic words, while long vowels and diphthongs occur in both open and closed syllables, as in: " beat "," boil " (Davenport and Hannahs 2005:51).They are as follows :

1. / eI / : It is front, half close to close with spread lips, as in:

" clay ", " maid ", " hay ".

2. / $\partial v /:$ It is back half close to close with rounded lips, as in:

" hole ", " go ", " low ".

10

3. / aI / : It is central open with lips neutral to close front with spread lips, as in: " lie ", "might ", and " tie ".

4. / av /: It is central open with lips neutral to close back with rounded lips, as in : "cow ", " bow ", and " owl ".

5. / II /: It is back open with rounded lips to front close with spread lips, as in : " boy ", " toy ", and "coil".

6. / г / : It is front close with spread lips to central half close with lips neutral, as in : " piere ", " fierce ", " carrier ".

7./ eə / :It is front half open with spread lips to central half close with lips neutral, as in : " air ", " fair ", and " pared ". 
8. / və / : It is back close with rounded lips to central half close with lips neutral, as in : " poor ", " gourd " (Robins 1980: 75).

\subsection{Triphthongs}

A triphthong is a glide from one vowel to another and to a third one without interruption. Mostly, in SE, the third vowel that is added is the central schwa / ə / to the five closing diphthongs becoming / агә, егә , эгә , ә๗ə , avə / as has been stated by Roach (2000: 24), as in: " layer "," liar ", " royal ", "lower", " power ". Another view sees that the diphthongs /eI, aI, गI, əv, a $/$ are falling, i.e. with length and stress on the first element; and closing, i.e. gliding from a more open to a closer position. All may be followed by / a / within the word, as in : "Noah", "fire", "society"," sour" ; or as a suffix that is appended to the root, as in: "player", "slower"," higher" ; or when a word final diphthong is followed by word initial /o /, as in: "they are", "buy a house"( Gimson 1989: 138)

\section{Sounds in Context}

Vowel and consonant segments combine into syllables; syllables combine into words; and words combine into phrases and sentences. But the process of producing connected speech affects the pronunciation of several of these segments in a number of interesting ways ( Crystal s.v. 247). Certain segments tend to run together as in assimilation; extra sounds may be added to obtain smoothness of speech as in the phonetic process of intrusion ; while some other segments may completely disappear in pronunciation as in the process of elision.

\subsection{Assimilation}

It can be defined as the phonetic process of replacing a sound by another sound similar to it under the influence of a third one which is near to it in the word or sentence, i.e., through word boundaries or with in words (Jones 2009: 217 Roach 2000: 138). It is more likely to be found in rapid, casual speech. Sometimes the difference caused by assimilation is very noticeable and sometimes it is very slight. The cases that have most been described are assimilations affecting consonants either progressively or regressively according to the direction of influence. They accordingly involve changes in voicing, place of articulation, and manner of articulation of sounds.

\subsubsection{Progressive Assimilation}

In this type of assimilation the direction of influence is from left to right, or forwards through a word as it progresses forwards .It is also called " preservative" as it preserves some aspects of a segment, beyond the segment from which it originates (Kuiper and Allen 1996 : 70), as in:

30. Happen $\rightarrow /$ hæpən/ $\rightarrow$ [ hæpm ]

The alveolar $/ \mathrm{n} / \rightarrow$ bilabial $/ \mathrm{m} /$ after $/ \mathrm{p} /$

31. It is dark $\rightarrow /$ ət əz da: $/ \rightarrow$ [ əts da:k ] 
The voiced / $/ \mathrm{z} \rightarrow$ voiceless $/ \mathrm{s} /$ after / $\mathrm{t} /$

It mostly causes assimilations in voicing when a verb carries a third person singular ' $-\mathrm{s}$ ' or a noun plural ' $-\mathrm{s}$ ' that suffix will be pronounced

as / s / if the preceding consonant is fortis" voiceless ", and as voiced /z/ if the preceding consonant is lenis " voiced " (Roach 1983: 107).

\subsubsection{Regressive Assimilation}

It is the type of assimilation in which the direction of influence is from right to left, or backwards through the word. It may be called' anticipatory assimilation ' because a segment is altered in a way which anticipates a phonetic property of a segment which comes later in a word or in word boundaries (Kuiper and Allen 1996: 70), as in:

32. Input $\rightarrow$ / Inpot $/ \rightarrow$ [ Impot ]

The alveolar $/ \mathrm{n} / \rightarrow$ bilabial $/ \mathrm{m} /$ before $/ \mathrm{p} /$

While Gimson (1989:298) identifies regressive assimilations as the instability of final alveolars. Word final /t, d, s, z / assimilate to the following word initial consonant $/ \mathrm{t}, \mathrm{d}, \mathrm{n} /$ are replaced by bilabials before bilabial consonants and by velars before velar consonants; / s, z / are replaced by palato-alveolars before consonants containing a palatal feature.

\subsubsection{Coalescent Assimilation}

Hassan and El-Shayib ( 1989 : 127 ) and Gimson ( 1989 : 299 ) define this type of assimilation as the fusion of two sounds into one. The sounds / t, d, s, z / when combined with palatal /y/ results in $/ \mathrm{t} /$, $/ \mathrm{d} 3 /, / \mathrm{J} /, / 3 /$ sounds respectively.It occurs also within words or word boundaries, as in the following examples:

75. Can't you do it? $\rightarrow /$ kænt ju: d $\mathrm{It} / \rightarrow$ [ kænt $\left.\int \mathrm{u}: \mathrm{d} \mho \mathrm{It}\right]$

77. Would you? $\rightarrow /$ wod jo $/ \rightarrow[$ wodzo $]$

\subsection{Elision}

It is a phonetic process whereby sound segments are elided or disappear unintentionally in speech . O'Connor (1980:103), Jones (2009:230), Gimson (1989:300) and Clark and Yallop 1995:90) state that in rapid casual speech sounds may be so weakly articulated in that they no longer have auditory significance in the stream of running speech. It refers to the omission of segment/s or whole syllables. It occurs different word positions, and can be defined differently accordingly. Aphaeresis is the elision of an initial segment from a word, syncope is the elision of medial segment/s , and apocope which is the elision of segments from final position of a word . It is often found in consonant clusters, as in" facts" and "chests" that are pronounced without [t], or "fifths" without $[\Theta]$. 


\subsubsection{Aphaeresis}

It refers to the elision of an initial sound in a word, examples include the historical loss of [k] in knife", and such contractions such as" I've" (Crystal s.v. 28). Aphasis is a type of aphaeresis which indicates the loss of an unstressed vowel at the beginning of a word, as in:

33. Again $\rightarrow$ ['geIn ]

34. About $\rightarrow[$ 'baut $]$

35. Especial $\rightarrow$ [' spe $ə 21]$

It also includes instances of the historical loss of consonant segments such as :

36.Wrong $\rightarrow$ [ roy ]

37. Knight $\rightarrow$ [ nat ] $\quad$ ( Hassan and El-Shayib 1989:132)

\subsubsection{Syncope}

It refers to the elision of a vowel, a consonant, or a whole syllable within a word (Crystal s.v. 449), as in the following examples :

38. Secretary $\rightarrow$ /sekritəri/ $\rightarrow$ [ sekritrI ]

39. Library $\rightarrow$ / laibrorI / $\rightarrow$ [ laibri ]

Hassan and El-Shayib(1989:132) states that such contextual elisions include syncope of / / when preceded by / o: / as in

40. always $\rightarrow /$ o:lweIz $/ \rightarrow$ [ o:weIz ]

Historical syncope include instances where the consonant segments / 1/, / $\mathrm{t} /$, are elided, as in "walk" and "castle".

\subsubsection{Apocope}

It refers to the elision of the final segment/s in a word, examples include the pronunciation of " an " as / on / or of " of " as / ə/, and in phrases such as the following :

41. Cup of tea $\rightarrow / \mathrm{k} \wedge \mathrm{p}$ əv ti: $/ \rightarrow[\mathrm{k} \wedge \mathrm{p}$ ə ti: $]$

42. Edinburg $\rightarrow$ /edinb3:g / $\rightarrow$ [ edmbrə ]

Apocope of final / t /, / d / is the most common in English. O'Connor 1980: 103; and Finch s.v. 44 state that the alveolar / $\mathrm{t} /$ is omitted after /s/, /f/ when the following word begins with either a stop, a nasal, or fricative sound as in the following examples:

43. Crest fabrics $\rightarrow /$ krest ferbriks/ $\rightarrow$ [ kres ferbriks ]

The /d /is omitted in / nd /, / md/ if the following word begins with a nasal or a weak stop consonant (ibid), as in the following examples:

44. It seemed good $\rightarrow$ / It si:md god / $\rightarrow$ [ It si:m god ]

\subsection{Intrusion}

It is another type of the phonetic processes whereby sounds affect each other but in a different way. Crystal ( s.v. 243 ) clarifies that " the traditional rhetoric has devised a classification of the types of intrusion in terms of the position of the extra sound which is added in a word". It is 
called "prothesis" in word-initial position , "epenthesis" in word-medial position, and " anaptyxis " in word-final position .

Hassan and El-Shayib (1989:134) provide a type of intrusion that occurs between word boundaries:

"when a word ends with a vowel followed by word that starts with a vowel intrusive $/ \mathrm{r} /, / \mathrm{w} /$, or $/ \mathrm{j} /$ replaces the glottal stop $/ \mathrm{P} /$ according to the type of the vowel or the diphthong, for $/ \mathrm{r} /$ replaces $/ \mathrm{\partial}, \mathrm{a}$ : , o: , Iə , eə, $\mho ə /$; the approximant / w / replaces / $\mho, a \mho,, \mho \mho /$; and / $/$ replaces / I , eI, aI, oI /"

The following are illustrative examples :

45. this is my article $\rightarrow /$ ठIs IZ maI a:trkl $/ \rightarrow$ [ ðIs IZ maI ja:tıkł ]

46. who are they? $\rightarrow$ / hu: a: ðeI / $\rightarrow$ [ hu: wa: ðeI ]

\subsubsection{Prothesis}

A term that is used in phonetics and phonology to refer to a type of intrusion, where an extra sound is inserted initially in a word, as in the following example:

47. Left turn $\rightarrow$ [ oleft t3:n ]

48. State $\rightarrow$ [ ostert ]

( Trask 2003:66)

49. Snob $\rightarrow[$ osnob $]$

\subsubsection{Epenthesis}

It is a type of intrusion which is used in phonetics and phonology to refer to the insertion of an extra sound that is added within a word. Stageberg (1981: 34) and Fromkin..etal (2003: 310)state that epenthesis occurs to fix up non permitted consonant sequences,"in English morphemes, the nasal /non- nasal consonant clusters must be homorganic : both labial, both alveolar, or both velar. We find $/ \mathrm{m} / \mathrm{before} / \mathrm{p} /$ and $/ \mathrm{b} /$ as in 'ample', and' amble' ". Roach ( 2009: 55) claims that epenthesis has occurred throughout the history of English, as in the earlier form of the words "empty", and "glimpse" that have had no "p's". as in the following examples:

50. Something $\rightarrow /$ s $\Lambda$ mӨing / $\rightarrow$ [ sımpӨing ]

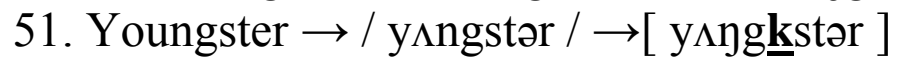

\subsubsection{Anaptyxis}

It is a term that is used in comparative philology, and sometimes in modern phonology to refer to a type of intrusion where an extra vowel is inserted word- finally between two consonants ( Trask 2003:67). Anaptyctic vowels are also known as parasite vowels, a vowel /o / is inserted in some accents of English in sequences such as $/ \mathrm{rm} /$ and $/ \mathrm{lm} / \mathrm{as}$ in the following examples:

52. Film $\rightarrow$ / film $/ \rightarrow$ [ filəm $]$ 
53. Alarm $\rightarrow$ / əla:m / $\rightarrow$ [ əla:rəm ] (Collins and Mees 2008:119)

Another opinion sees that the addition of an extra consonant to the end of a word is called epithesis, and it occurs after final $/ \mathrm{n} /$ or $/ \mathrm{s} /$. The word "sound" has an origin of "soun" in Medieval English. There is another instance where an epithetic / $/$ / appears after final /s/, it is caused by the fact that the tongue instead of being lowered to end the /s/ sound, is pressed against the alveolar ridge while the breath is moving outwards; then, when the tongue is lowered, the release of air pressure produces a $/ \mathrm{t} /$, as in:

116. Across $\rightarrow$ /okros $/ \rightarrow$ [ okrost $]$

117. Wish $\rightarrow / \mathrm{wI} / \rightarrow[$ wI $f$ t] $\quad$ (Stageberg 1981:34)

\section{Conclusions}

Segmental phonemes in SE can be analysed to its immediate constituents of consonants segments and vowels segments with variable allophones each. Sounds are affected in their production in rapid casual speech, they are either assimilated ; elided ; or being inserted all in an attempt to color the whole acoustic impression of a foreigner's speech or else to distort it, as some Arabic learners would say. It is important that learners have knowledge about SE sound segments and sounds in context.

Types of assimilation including changes in direction, from right to the left is called progressive, from left to the right is called regressive, and coalescent when the change is mutual must find practical applications in learning SE . Intrusion of the vowel /o/ is a type of prothesis in English , epenthesis includes the insertion of $/ \mathrm{p} /, / \mathrm{k} /$, and anaptyxis in which $/ \mathrm{\partial} /$ is inserted finally in a word. Elision in SE includes aphaeresis in which the vowel /e/ is elided and the historical aphaeresis of /w/, syncope of $/ \mathrm{I} /, / \mathrm{a} /$, $/ \mathrm{d} /, / \mathrm{b} /$, and the historical syncope of $/ 1 /, / \mathrm{t} /$, apocope in which SE /t/ , /d/ is available in rapid casual speech. 


\section{References:}

Abercrombie, David (1971) Elements of General Phonetics

Edinburgh : Edinburgh University Press.

Carr, Philip (2009) English Phonetics and Phonology.Oxford Blackwell

Publishing Company.

Catford, J.C. (1977) Fundamental Problems in Phonetics.

Edinburgh : Edinburgh University Press.

Clark, John and Collin Yallop (1995) An Introduction toPhonetics and Phonology . Oxford : Blackwell.

Cohen, Abigail (2003)The Handbook of Linguistics :Phonology .Edited by

Mark Aronoff and J.Rees-

Miller. Malden : Blackwell.

Collins, Beverley and Inger M. Mees (2008) Practical Phonetics and Phonology $.2^{\text {nd }}$. ed. London : Routledge.

Crystal, David (2003) The Cambridge Encyclopedia of the English Language $.2^{\text {nd }}$.ed. Cambridge : Cambridge University Press. (2003) A Dictionary of Linguistics and Phonetics .

$6^{\text {th }}$. ed.---

Davenport, Mike and S.T. Hannahs (2005) Introducing Phonetics and Phonology . $2^{\text {nd }}$.ed.London : Hodder Arnold Education.

Finch, Geoffrey(20o5) Key Concepts in Language and Linguistics . $\quad 2^{\text {nd }}$. ed. London : Palgrave MacMillan.

Fromkin, V., Nina Hymes, and R. Rodman (2003) An Introduction to

Language $.7^{\text {th }}$. ed. New York : Holt, Rinehart, and Winston.

Gimson, A.C. (1980) An Introduction to the Pronunciation of

English . $3^{\text {rd }}$.ed. London : Edward Arnold. (1989) An Introduction to the Pronunciation of

English . $4^{\text {th }}$ ed. New York : Routledge.

Hassan, M. and Muhammed El-Shayib(1989) English Pronunciation for Student Teachers . $2^{\text {nd }}$. ed. Baghdad: Ministry of Education Press.

Hudson, Grover (2000) Essential Introductory Linguistics.

Mass.:Blackwell Publishing Company.

Jones, Charles (2006) English Pronunciations in the Eighteenth and Nineteenth Centuries. New York : Palgrave MacMillan.

Jones, Daniel ( 2009) An Outline of English Phonetics.14 ${ }^{\text {th }}$.ed. New Delhi :

Kalyani Publishers.

Kuiper, Koenraad and Scott Allan (1996) An Introduction to English Language : Sound, Word, and Sentence .London : The Bath Press.

Ladefoged, Peter (2006) A Course in Phonetics. $5^{\text {th }}$.ed.

Massachusetts : Thomson Wadsworth.

Mac Mahon, April (2002) An Introduction to English Phonology . Edinburgh :Edinburgh University Press.

O'Connor, J.D.(1980) Better English Pronunciation .Cambridge : Cambridge University Press.

Rajimwale, Sharad (2007) Elements of General Linguistics $.8^{\text {th }}$.ed. New Delhi :

Rama Brothers.

Roach, Peter (2000) English Phonetics and Phonology . $3^{\text {rd }}$.ed.

Cambridge : Cambridge University Press. 
(2002) A Little Encyclopedia of Phonetics . on the Website: http://www. linguistics.reading.ac.uk. /staff/Peter Roach. Email : p.j. roach @ reading. ac. uk.

-------- (2009) Phonetics . Oxford : Oxford University Press.

Robins, Robert Henry (1980) General Linguistics : An Introductory $3^{\text {rd }}$.ed. New York : Longman.

Stageberg, Norman C. (1981) An Introductory English Grammar .

New York : Holt, Rinehart, and Winston.

Survey

$4^{\text {th }}$. ed.

\section{تحليل فونولوجي للأصوات في اللغة الانجليزية

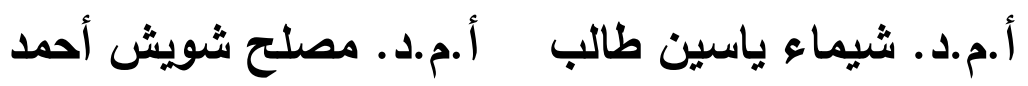

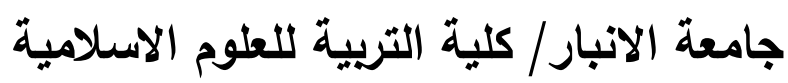

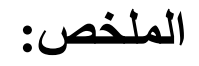

البحث يتناول التحليل الفونولوجي للأصوات الساكنة الصحيحة مع الوفوناتها في اللغة الإنجليزية و تتابع

السواكن في المقطع الواحد و أصوات العلة والوفوناتها المنتوعة الى جانب وصف وتحليل بعض التغييرات الفونولوجية و تفرعاتها منل الإدغام و الحذف و الزيادة التي تحدث خلال الكلام السريع و المترابط لتقديم كلام منمق. يهدف البحث إلى تقديم فروع هذه التغييرات الفونولوجية مثل الإدغام المتبادل و حذف الوسطية والزيادة

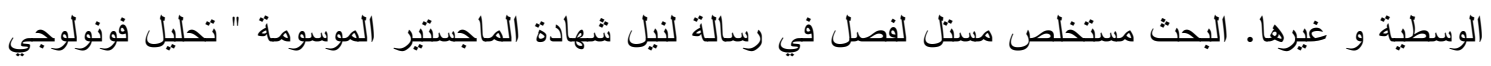
للأصوات في اللغة الانجليزية و لهجة هيت العراقية" . 